\title{
Basel capital requirements, portfolio shift and bank lending in Africa
}

\author{
Damilola Oyetade, Adefemi A. Obalade, Paul-Francois Muzindutsi* \\ University of KwaZulu-Natal, South Africa
}

\section{ARTICLE INFO}

Article history:

Received 08 May 2021

Revised 23 September 2021 and 19

October 2021

Accepted 23 November 2021

Published 23 December 2021

Keywords:

Bank lending

Portfolio shift

Basel capital requirements

Africa

JEL codes: G28, G21, G17

\section{ABSTRACT}

Bank lending is a major source of income for a bank. Compliance with higher Basel capital requirements (CAR) portends serious implication for distribution of loan portfolio across different sectors. The objective of the study is to examine African banks' responses to higher CAR in terms of portfolio shift. The study used descriptive statistics and ANOVA for panel data of African commercial banks that have implemented Basel II or III CAR for the period 2000 and 2018. Based on the results of our analysis, implementation of higher Basel CAR by African banks revealed four key findings. Firstly, our results suggest that higher Basel CAR particularly Basel III reduced total loans for South African banks. Secondly, African banks engage in portfolio shift with higher Basel levels. Thirdly, higher Basel capital increased banks' capital ratios in Africa, but some banks are still characterized by low equity. Fourthly, African banks reduce lending to high risk-weighted loans such as real estate and commercial loans except for South African banks which increased lending to commercial loans with higher Basel CAR. Lastly, this study proffers key insight into the lending behaviour of African banks with the implementation of higher Basel CAR.

\section{Introduction}

Since the 1990s, African economies have experienced accelerated economic growth (Mecagni, Marchettini, \& Maino, 2015). The robust economic growth in Africa is attributed to the expansion of access to financial services, upgraded regulatory and institutional capacities of the commercial banks (Mecagni et al., 2015). Additionally, African banks remain highly profitable as measured by net interest income and return on assets (Chironga, Cunha, Grandis, \& Kuyoro, 2018). Despite these achievements, African banking systems lack depth compared to the rest of the world (European Investment Bank, 2016). Comparing Africa to other regions, there has been an increase in bank lending since 1990. Still, bank loans to the private sector declined by 23.5percent in the last ten years in Africa, while bank loans to the private sector declined in the same period by marginally 0.92percent in the United States. South and East Asia witnessed an increase in bank loans to the private sector by an average of 23.6percent (World Bank, 2020). In

\footnotetext{
* Corresponding author. 
the aftermath of the 2008 global financial crisis in the developed countries, African countries became affected by the spill-over effect such as fall in aids and foreign direct investments from donor countries battling with recession, having consequences for the African economy and the financial sector as a whole (Allen \& Giovannetti, 2011; Sanusi, 2010). In addition, African banks inability to improve capital adequacy, accentuated by weak consumer demands, fall in global output, and unstable exchange rates, affected Africa through both the financial and real (trade, remittances, and aid) channels (Allen \& Giovannetti, 2011; Sanusi, 2010).

In response to the global financial crisis, the Basel Committee revised Basel II through the introduction of Basel III. The key elements of the latter are an increase in CAR. The social benefits of higher CAR entail promoting a healthy financial system, lowering the probability of bank failure, and increasing lending activities, which may ultimately increase economic activities (Admati, DeMarzo, Hellwig, \& Pfleiderer, 2013; BCBS, 2017). However, implementing higher CAR may affect banks' ability to supply loans (Ambrocio \& Jokivuolle, 2018; Jablecki, 2009; Neethling, 2014). As a result, higher Basel capital induces banks to raise the cost of lending to customers, which may negatively impact bank lending and, consequently, harm economic growth (Ljung \& Schennings, 2018; Psillaki \& Georgoulea, 2016). In addition, competition for scarce equity capital may play an essential role in the allocation of credit. For instance, Berger, Herring, and Szegö (1995) state that increasing capital might alter bank behaviour to choose portfolios with different risk and return profiles. In other words, the risk-weights in various Basel accords can influence how banks allocate funds in their loan portfolios, known as portfolio shift behaviour (Bruno, Nocera, \& Resti, 2017) because capital is tied to the portfolio risk of banks to prevent excessive risk. In essence, the impact of higher capital is two ways. The more capital banks have, the more robust their buffers to absorb unexpected losses and the more ability for banks to lend and is healthy for economic growth (Bikker \& Vervliet, 2018). Conversely, banks can cut back the supply of loans in response to an increase in regulatory CAR, changes in monetary policy or government directives, or hike in interest rates (Ambrocio \& Jokivuolle, 2018; Jablecki, 2009).

Bank lending is a major source of income to a bank and is assumed to positively affect banks' performance (Datta $\&$ Mahmud, 2018). Although the purpose of higher CAR is to reduce the probability of a banking crisis (BCBS, 2017; Gavalas, 2015), it is imperative to investigate its effects on banks' lending ability, especially for banks in Africa. Basel regulations are created to provide adequate capital requirements to guard against risk, such as credit risk in bank loan books arising from lending (Balin, 2008). Nevertheless, regulatory authorities in African countries perceive the implementation of higher Basel CAR to be stringent. Many African countries are slow in embracing higher Basel capital requirements than South Africa, Egypt, and Mauritius that have progressed to implement Basel III CAR (Kahari, 2016). As a result, bank lending ability remained low with high non-performing loans, leading to a lack of financial depth and inefficient financial intermediation (Waithaka, 2013).

Furthermore, the banking sector in many African countries remains under-developed; thus, African banks are yet to fully integrated into the global financial system (Demetriades \& Fielding, 2012; Kahari, 2016). For instance, there are gaps in capital adequacy, which often restrict the capacity of African banks to finance loan demands to customers (Okoye, Adetiloye, Erin, \& Evbuomwan, 2017; Waithaka, 2013). Hence, most of the loan facilities provided by African banks are short-term, having a maximum maturity of one year. Also, many banks in Africa are excessively liquid for fear of bad loans (Andrianova, Baltagi, Demetriades, \& Fielding, 2015; Asongu \& Odhiambo, 2018). 
Excess liquidity is a feature of financial underdevelopment, suggesting low loan output. African banks complain of lack of grade quality borrowers. At the same time, households and corporates find a lack of access to bank financing as a significant constraint in Africa (Asiama \& Amoah, 2019; Asongu \& Odhiambo, 2018; Balin, 2008) whereas corporates and SMEs rely on banks for over 76percent of their financing in Europe (Berger, 2017).

Implementation of Basel I and II CAR has been credited for increasing capital ratios and credit expansion in the developed countries (Jablecki, 2009). Also, the implementation of Basel ICAR in Nigeria and Basel II CAR in South Africa increased credit expansion (Sanusi, 2010; Soile-Balogun, 2017). The advancements in the implementation of change from Basel II to Basel III CAR by South Africa, Egypt, Mauritius, and Morocco show that African banks have the ability to adopt higher CAR. It is imperative to examine African banks' responses to higher CAR in terms of portfolio shift.

In compliance with higher CAR, banks may engage in portfolio shifts towards loans with low risk-weights to avoid capital holding. Engagement in portfolio shift could lead to loan concentration in a certain loan category relative to total loans, which may result in higher credit risk relative to bank's total portfolio risk, as witnessed in the Japanese 1998 financial crisis and the 2008 financial crisis where many bank failures arose from excessive lending to the real estate (Iwatsubo, 2007; Walter, 2019). This study examines the bank behaviour to the current Basel rules specifically, what types of loans the banks engaged in with higher CAR and the likely effects on bank lending in Africa. The objective of the study is to examine African banks' responses to higher CAR in terms of portfolio shift.

\section{Theoretical and empirical literature review}

Certain theories explain bank lending behaviour in response to higher CAR. The relevant theories include the modern portfolio theory and the static trade-off theory. These theories and the reviewed empirical studies on Basel CAR and portfolio shift are presented in this section.

\section{The Modern Portfolio Theory}

The Modern Portfolio Theory (MPT) posits that a firm can attempt to maximize the expected return on a portfolio of assets for a given level of portfolio risk (Bennett, 1984; Waithaka, 2013). MPT provides insights into how a bank can balance its loan portfolios' riskiness to maximize returns (Bennett, 1984), but how does it simultaneously achieve its minimum regulatory CAR? A bank portfolio comprises of different loan categories having different risk exposure. These risks must be adequately managed; thus, the Basel accords provide standardised risk weights for different loan categories for adequate capital against such risk in the banks' loan portfolios. As a result, the changes in Basel CAR and the bank's capital positions can influence bank decisions on lending, particularly the distribution of loans between low-risk weighted assets and high-risk weighted assets (Bruno et al., 2017; Haubrich \& Wachtel, 1993). A wellcapitalized bank has more capacity to expand and diversify loans into commercial lending, consumer lending, residential and commercial mortgage, credit card loans, among others, to minimize risk, maximize returns, and, at the same time, meet the minimum CAR (Waithaka, 2013). These banks generally remain strong even when a number of borrowers default (Bennett, 1999). Contrariwise, banks with low capital ratios adjust loan portfolio by decreasing 
lending with high risk-weight like commercial loans and increasing loans with low risk-weight to improve their banks capital ratios which may reduce returns to shareholders. The question is: do African banks increase or decrease loans with low and high risk-weight to maximize returns and achieve higher capital?

\section{The static trade-off theory}

The static trade-off theory states that "optimal capital structure is reached when the tax advantage to borrowing is balanced at the margin by the costs of bankruptcy" (Myers, 1984, p. 2). The theory is based on the trade-off between the benefits and the cost associated with debt and equity sources of funds (Mapororo, 2018). The implication of this theory for banks; is that a bank may have reached a set optimal capital structure; thus, adopting a new Basel CAR to comply with regulatory authorities may impose new cost constraints (Admati et al., 2013). Since debt is cheap, banks will prefer to hold more debt than equity because of the tax benefit of debt. However, Basel III CAR requires banks to use equity capital to achieve higher CAR because a firm with too much debt is prone to bankruptcy (Mapororo, 2018).

Higher equity capital leads to a fall in return on equity because shareholders face lower risks of bankruptcy (Berger et al., 1995; Cummings \& Wright, 2016). Thus, for higher CAR, it is expected that banks will seek higher return on equity above its cost of equity to create value for their shareholders (Perrone, Ferreira, \& Securato, 2015). Compliance to higher Basel CAR forces banks to hold capital above the optimal level which can likely impact banks' lending ability (Osborne, Fuertes, \& Milne, 2012). Also, achieving higher CAR can influence portfolio shifts depending on the level of individual bank's equity before the introduction of Basel III CAR. In this context, the portfolio shift behaviour of banks may be different under Basel III CAR. From the foregoing, based on the static trade-off theory and Basel III CAR, it is expected that compliance with higher Basel CAR increase risk behaviour of banks: shifting towards loans with high-risk weights such as commercial loans, commercial mortgages for higher returns.

\section{Empirical studies on Basel CAR and portfolio shift}

Following the introduction of Basel I CAR's in 1988, banks in the US reduced their lending to corporate lending and simultaneously began investing in government securities (Furfine, 2001). As a result, corporate lending fell by six percentage points between 1989 and 1994 while US government securities increased by ten percentage points in the same period, contributing to the credit crunch (Dionne \& Harchaoui, 2008; Furfine, 2001; Sanders, 2015). Following the credit crunch of 1990 in the US, many empirical studies have been carried out to determine the extent to which changes in Basel CAR were responsible for shift in bank portfolio. These studies focus on identifying whether the decline in lending was caused by the credit crunch or the introduction of the Basel I capital ratio.

Bernanke, Lown, and Friedman (1991); Furfine (2001); Haubrich and Wachtel (1993) use various techniques and different definitions of capital ratio to examine whether changes in Basel capital influence banks portfolio shift from loans with high-risk weights towards loans with low-risk weights. The conclusions from these US studies were that the impact of higher capital on optimal loan portfolio allocation of banks contributed to the 1991 credit crunch. For instance, Haubrich and Wachtel (1993) find strong evidence between Basel regulatory capital ratio changes and bank 
portfolios' shift in the United States. Their study shows that US banks shifted from commercial loans to low-risk assets such as cash and government securities with zero risk-weights. This suggested that if a bank finds it difficult to meet its CAR, it can shift away from high risk-weighted loans like corporate loans to government securities having zero risk-weight (Haubrich \& Wachtel, 1993). On the contrary, Hancock and Wilcox (1994) find that undercapitalised banks take on risky loans. Moreover, these studies were done in the era when banks issued debts to achieve minimum capital ratios.

Studies from other countries have mixed findings arising from different sample data, time periods, different capital variable definitions. In the emerging countries, Nachane, Narain, Ghosh, and Sahoo (2000) find that higher CAR did not have a significant portfolio shift effect for Indian banks, whereas Ashok and Abhiman (2002) found a contrary view as portfolio shift was more significant in large Indian banks towards government securities to reduce capital holdings. Basel I and Basel II accords, may have incentivized banks, especially in the developed countries to increase portfolio risk arising from capital arbitraging, and financial innovations such as securitization to convert illiquid loans in banks' balance sheet for liquidity (Jablecki, 2009; Nachane et al., 2000). The capital arbitrage enabled the banks to increase lending without increasing capital against such risk which contributed to the 2008 global financial crisis. In the UK, Basel II was implemented during the 2008 financial crisis, as a result, the effect of the fall in risk-weights for residential mortgage under Basel II CAR was not felt, as banks declined lending to mortgages despite the fall in capital requirements for mortgages (Benetton, Eckley, Garbarino, Kirwin, \& Latsi, 2020). Basel III requirements introduced capital charge for securitization exposure, to eliminate regulatory arbitrage (BCBS, 2009, 2016). In Africa, the financial market lacks depth, and securitization exposure through the conversion of illiquid loans to liquidity is low. Therefore, it is expedient to examine the lending and portfolio shift behaviours of African banks in response to changes in higher CAR from Basel II to Basel III.

Following the 2008 financial crisis and the introduction of the Basel III accord, banks' equity capital has increased considerably to reduce the probability of bank failures (Walter, 2019). However, there are trade-offs between reducing the likelihood of bank failures and how loan is allocated across sectors in the economy (Ambrocio \& Jokivuolle, 2018). Basel III CAR affects banks differently depending on their pre-capital ratios (Juelsrud \& Wold, 2020). Juelsrud and Wold (2020) examine the change in lending behaviour of Norwegian banks around the Basel III implementation period (2012-2013) and find that portfolio shift was more significant for smaller Norwegian banks. Although there was a significant increase in capital ratios of banks especially the low-capitalised banks, it was accompanied by a significant decline in high risk-weighted corporate loans and rise in low risk-weighted consumer loans around the Basel III implementation period (Juelsrud \& Wold, 2020). Furthermore, Junge and Kugler (2013) show that a portfolio shift in response to higher capital is expensive notably for large banks in Switzerland given that competition is fierce, and most banks already meet the Basel III CAR before implementation.

A shift in bank portfolio can be described as decisions made by banks to adjust their portfolio loan allocations across different sectors over time, affected by risk-weights used to set capital ratios by banks (Ambrocio \& Jokivuolle, 2018; Furfine, 2001). The risk weight system of the Basel I, II, and III accords can disproportionately constrains banks from lending to high risk-weighted loans such as commercial loans, commercial and residential mortgages, due to the presumption that such loans are risky even when some of the loans are quality loans (Admati et al., 2013; 
Ambrocio \& Jokivuolle, 2018). As a result, lending for such loans with high-risk weight is relatively expensive. Juelsrud and Wold (2020) find that for Norwegian banks, one percent increase in CAR, reduces loans to corporate sector by 1.0-1.4 percent. In addition, when banks are failing to meet up with minimum capital, they are motivated to shift their portfolio away from such loans to low risk-weights such as government securities that attract zero riskweights (Abdel-Baki, 2012; Furfine, 2001). Nevertheless, banks may take on riskier loans when there is a gap in meeting minimum CAR (Dionne \& Harchaoui, 2008; Jablecki, 2009).

The empirical literature identifies four reasons banks engage in shift in portfolio: (1) to achieve higher CAR, (2) lower demand in loans arising from recession, (3) more regulatory pressures, (4) secular trends (Dionne \& Harchaoui, 2008; Haubrich \& Wachtel, 1993). Furthermore, banks can shift away from certain loans depending on their incentive for risk-taking or the state of their financial situation and the business cycle (BCBS, 2010; Noss \& Toffano, 2016). For instance, Wells Fargo, the fourth-largest bank in the United States, declared a decline in fee income at the end of the first half of 2018 arising from avoiding riskier loans, which led to lower expected profits and affected the firm's stock price (Moise, 2018).

Studies (Bruno et al., 2017; Derina, 2011; Ruthenberg \& Landskroner, 2008) that consider effect of Basel capital's risk-weights on portfolio shifts from a bank stability point of view find that large banks favour low-risk customers while small banks favour high-risk customers. Ruthenberg and Landskroner (2008) examine the possible impact of Basel II CAR on the pricing of bank loans for Isreali banks. The study finds that large banks retain quality corporate and retail customers (cherry-picking) and probably adopt the internal approach to achieve target capital (Ruthenberg \& Landskroner, 2008). High-risk borrowers will benefit from smaller banks. Furthermore, the smaller banks will adopt the standardized approach for lack of skilled personnel to adopt the Basel II internal approach to calculate riskweighted assets in determining their capital ratio. Similar to these findings, Bruno et al. (2017) find that smaller banks in Europe take on loans with higher risk-weights as their balance sheet showed a larger share of corporate loans. Furthermore, Derina (2011) using a partial adjustment model between capital and risk finds similar findings for Indonesian banks, suggesting that smaller banks are risk-takers while large banks are risk-averse as large bank shift towards loans with lower risk weights to hold less capital and smaller banks tend to hold more capital. Derina (2011) notes that the profitability of banks with high-risk portfolio declined while profits of large banks with low-risk portfolio increased.

From the foregoing, banks tend to alter the supply of loans in compliance with an increase in regulatory CAR (Ambrocio \& Jokivuolle, 2018; Bernanke et al., 1991). As a result, the elasticity of the supply of loans is higher when the capital ratio is low. Other things being equal, well-capitalized banks are better positioned to absorb shocks. Such well-capitalized banks adjust lending less frequently to avoid regulatory capital shortfalls than banks with low capital ratios (Tabak, Noronha, \& Cajueiro, 2011). Hancock and Wilcox (1994) find that the US under-capitalised banks take on risky loans. This was because banks in the developed countries did not incur penalties for non-compliance to the regulatory minimum CAR (Jablecki, 2009). Ashok and Abhiman (2002) find that under-capitalised and overcapitalised banks in India engage in portfolio shifts towards low-risk loans to avoid holding more capital. According to Furfine (2001), banks would be less inclined to deviate from regulatory requirements if there was a cost (such as penalties) associated to breaching the Basel requirements, which can have significant impact on bank lending 
behaviour. In Africa, Neethling (2014) show that South African banks did not substitute loans with higher risk weights for loans with lower risk weights to achieve higher CAR. This is because the banks already hold capital above the minimum regulatory CAR to avoid penalties for falling below the minimum CAR (Nkopane, 2017).

Contrary to Neethling (2014), Ambrocio and Jokivuolle (2018) evaluate the quantitative impact of higher capital on portfolio shift under the different regulatory regime (risk-based and less risk-sensitive capital) for US banks. Their study set a ratio of productivity between the riskier and safest sectors in the US manufacturing industry and estimated a welfare loss of adopting higher capital on the assumption that all sectors are equally productive. Their findings suggest that risk-based capital distorts credit allocation, favouring safe borrowers than risky borrowers (Ambrocio \& Jokivuolle, 2018). Existing studies such as Ruthenberg and Landskroner (2008) and Ambrocio and Jokivuolle (2018) use probability of default in their loan model; these models do not account for portfolio shifts on loans categories the banks cut lending from. Thus, their loan models did not provide the loan categories (such as corporate, credit card loans, commercial mortgage, residential mortgages) banks moved away from/to in response to higher capital in their study. Their study findings could only show behaviour of banks between low risky and high risky borrowers.

For instance, retail and commercial mortgage are long term loans with high-risk weight that require banks to hold down capital for the duration of the loan period, but banks in the developed countries, consider real estate loans as safe. In this context, despite the credit crunch of 1990 in the United States, the banks declined lending from commercial and consumer loans but still retained real estate loans (Bernanke et al., 1991). Furthermore, Japanese banks also retain mortgage loans in their portfolio, even when asset prices were falling before the Japanese 1998 financial crisis according to Iwatsubo (2007). The US and European banks followed a similar pattern before the 2008 financial crisis (Carbó-Valverde, Marqués-Ibáñez, \& Rodriguez-Fernandez, 2011). In African banks, most of the loan facilities provided are short-term, having a maximum maturity of one year. It is imperative to examine African banks' responses to higher CAR in terms of portfolio shift following the approach of Haubrich and Wachtel (1993); Nachane et al. (2000); Neethling (2014) who examine whether banks shift their portfolio in response to higher capital using non-regression, simulation, or calibration approach.

In summary, many African banking sectors are lagging in compliance with changes in Basel CAR. However, the banks are not new to regulatory changes as most have undergone major banking reforms in the past. To the best of the researchers' knowledge, the review of existing studies shows that the topic of portfolio shift behaviour of African banks to changes in Basel CAR is thinly investigated. It is imperative to determine whether higher capital is beneficial for banks in Africa to avoid CAR that will further decrease lending ability given that African banks are already characterised with low lending, short term loans, and excessively liquid arising from fear of non-performing loans. Therefore, it is the goal of this study to examine the portfolio shift behavior of banks in Africa to changes in Basel CAR.

\section{Methodology}

Data and variable description 
This paper uses a quantitative approach using accounting ratios defined in Table 1 to analyse the study objective. It presents the justification for using descriptive statistics and ANOVA for portfolio shifts. The dataset is a panel of African commercial banks between 2000 and 2018. The sample period extends before the introduction of the Basel II accord in 2004 and the Basel III accord in 2009. This dataset and time period allow us to observe portfolio shift behavior of banks before and after Basel implementation.

Additionally, the sample period allows us to observe bank lending behaviour with higher Basel CAR. The dataset is the annual financial reports of the African banks obtained from Bloomberg, Infront and S\&P capital IQ databases. The population included 137 commercial banks listed on stock exchanges in the respective African countries. The criterion for sample inclusion is that the bank must comply with either Basel II or Basel III CAR during the sample period. In order words, banks that are not in compliance with Basel II or III CAR were dropped. As a consequence, our final sample size is an unbalanced panel of 41 banks that have adopted Basel II or III from 13 African countries and with comprehensive and available data. This study's objective is to examine whether the implementation of higher CAR leads African banks to shift their loan portfolio to less-riskier assets. For a robust comparison, the study examines the impact of the change from Basel II to Basel III on bank portfolio shift in Africa. The description of the variables used in this study is summarised in table 1 below.

Table 1. Definition of variables

\begin{tabular}{|c|c|c|}
\hline Variables & Definition & Formula \\
\hline Loangrowth $h_{i t}-L_{i t}$ & Bank lending proxied by Loan growth & Percentage change in total loans \\
\hline Baselcap $_{i t}-$ Cap $_{i t}$ & Basel IV capital ratios & Tangible common equity/RWA \\
\hline Roe & Bankspec Cost of capital & Profit/Total Assets \\
\hline Nplta & Bankspec & Non-performing asset/total loan \\
\hline Bank size & Bankspec & Quintiles of total assets \\
\hline Deposit to total assets & Bankspec-liquidity & Deposit/Total assets \\
\hline
\end{tabular}

Source: Authors' own compilation (2020)

$L_{i t}$ is proxied by loan growth, which is the percentage change in total loans (Berrospide \& Edge, 2010). Cap it Basel III capital ratio is defined as tangible common equity (TCE) divided by risk-weighted assets (RWA) according to the Basel III accords (BCBS, 2017; Yan, Hall, \& Turner, 2012). The TCE (numerator) consists of common equity, which is made up of common shares, retained earnings, and other reserves. The risk-weighted assets (denominator) consist of risk weight assigned to each category of bank assets in the balance sheet (loans-mortgage, corporate loans, government securities, and interbank borrowing).

The Bank-specific variable is the cost of capital is proxy by the return on equity (ROE) (Dionne \& Harchaoui, 2008; Roulet, 2018). In theory, the higher the cost of equity capital, the more expensive achieving higher capital 
becomes, which decline lending, ceteris paribus (Dionne \& Harchaoui, 2008). Nplta is proxy by non-performing loans to total assets.

\section{Estimation techniques}

To examine whether the implementation of higher CAR leads African banks to shift their loan portfolio to low risk assets, the study employs descriptive statistics and ANOVA to achieve this step. A portfolio shift occurs when banks either move to loans with lower risk-weight assets than loans with higher risk-weight assets or vice-versa. ANOVA is used for comparison to establish whether existing Basel CAR constrains or improves bank lending. The comparison examined the shift in bank loans according to bank assets (total loans, commercial loans, consumer loans, credit-card loans, residential mortgage, and commercial mortgage loans) in line with Haubrich and Wachtel (1993). ANOVA is employed over regression analysis because, firstly, ANOVA does not impose a linear assumption between the Basel capital ratios and the loan assets (Haubrich \& Wachtel, 1993). Secondly, ANOVA allows for comparing the effects of CAR on loan growth and how such effects differ on each loan asset category. In addition, ANOVA facilitates the interpretation and the interaction effects of capital on bank loan growth between different sizes of banks. The ANOVA tests employed are F-test (parametric test) and the Kruskal-Wallis test (non-parametric test). The F-test is based on the assumption of normal distribution and equal variance about bank loans. The F-test is given as:

$$
\begin{aligned}
& S S_{B}=\sum_{g=1}^{G} n_{g}\left(\check{x}_{g}-\check{x}\right)^{2} \\
& S S_{w}=\sum_{g=1}^{G} \sum_{i=1}^{n_{g}}\left(x_{i g}-\check{x}_{g}\right)^{2}
\end{aligned}
$$

Where $\breve{x g}$ is the sample mean within-group $g$ and $\breve{x}$ is the overall sample mean. And $i=1, \ldots . n_{g}$ for groups $g=$ $1,2, \ldots \ldots . G$. The $F$-test for the mean equality of group is computed as:

$$
F-\text { test }=\frac{S S_{B} /(G-1)}{S S_{W} /(N-G)}
$$

Where $N$ is the total number of observations, $G-1$ numerator is the degrees of freedom (DOF), and $N-G$ denominator is degrees of freedom under the null hypothesis of independent and identical normal distributed data, with equal means and variances in each subgroup (Welch, 1947). For the F-test's validity and reliability, the study must pass one of the F-test assumptions of equal variance (Hamilton, 2003). Where the loan data fails the equal variance assumption, the study equally applies the Kruskal-Wallis test because it provides a non-parametric alternative test where equal variance assumptions of the F-test are in doubt (Hamilton, 2003). Therefore, for confirmatory results for all the variables using F-test, a Kruskal-Wallis $(K W)$ test was performed. The KW test is given by the following formular: 


$$
K W=\left(\frac{12}{N(N+1)} \sum_{J=1}^{K} \frac{R_{j}^{2}}{n_{j}}\right)-3(N+1)
$$

Where $N$ represents the whole number of observations, $R_{j}^{2}$ is the average rank of observations in the $j t h$ group, $n j$ is the total number of observations in the $j$ th group, $k$ is the number of periods.

\section{Results and discussion}

This session presents the descriptive statistics of loan growth and Basel capital ratios variables, followed by ANOVA for portfolio shifts, the interpretation and discussion of the results.

\section{Descriptive analysis of key variables}

Table 2 presents the summary statistics of loan growth and Basel capital ratios. The annual growth in total loans averages 22.8percent over the sample period, while the standard deviation $(s d)$ is 55.8percent. This is an indication of low lending over the sample period. Basel II capital ratio (BII_capratio) measured using the Basel II capital requirements showed that the average capital ratio is 16.07 percent, and $s d$ is 5.7percent. The average mean of 16.7percent shows that African banks are well-capitalized above the minimum CAR, but the $s d$ of 5.7percent for BII_capratio shows that there are banks in Africa below the 8percent Basel II CAR. For the Basel III capital ratio (BIII_capratio), the mean and sd are 18.2percent and 7.2percent, respectively. Under BIII_capratio, the average capital ratio increased as shown with the $s d$; however, the banks still fall below the 10.5percent of Basel III capital requirement. The figure arises because some African banks have a low level of equity capital (the numerator of the Basel III capital ratio). Thus, this suggests that for some banks in Africa to comply with the higher Basel III CAR, they will have to raise more equity capital.

Table 2. Summary statistics of key variables

\begin{tabular}{llllllll}
\hline Stats & Mean & $\boldsymbol{N}$ & Min & Max & SD & Variance & skewness \\
\hline loan_growth & 22.85 & 687 & -89.96 & 640.05 & 55.8 & 3113.15 & 5.21 \\
BII_capratio & 16.07 & 449 & 5 & 46 & 5.72 & 32.77 & 1.45 \\
BIII_capratio & 18.22 & 477 & 2.9 & 73.81 & 7.18 & 51.56 & 2.17 \\
Nplta & 3.57 & 575 & 0.03 & 48.53 & 4.84 & 23.4 & 4.62 \\
\hline
\end{tabular}

Source: Authors' calculation (2020)

Figure 1 presents the lending growth and loan quality of banks in Africa between 2000 and 2018 for banks represented in the sample from 13 African countries. Lending has increased steadily over the past decade. During the period of financial crisis 2007-2009, the African banks had a significant increase in the volume of loans up to the year 2012. The graph shows that although the mean volume of total loans has been fairly increasing. In terms of lending growth, on average, it has been declining since 2012. This decline may affect the banks' performance. 


\section{Lending Growth and loan quality in Africa}

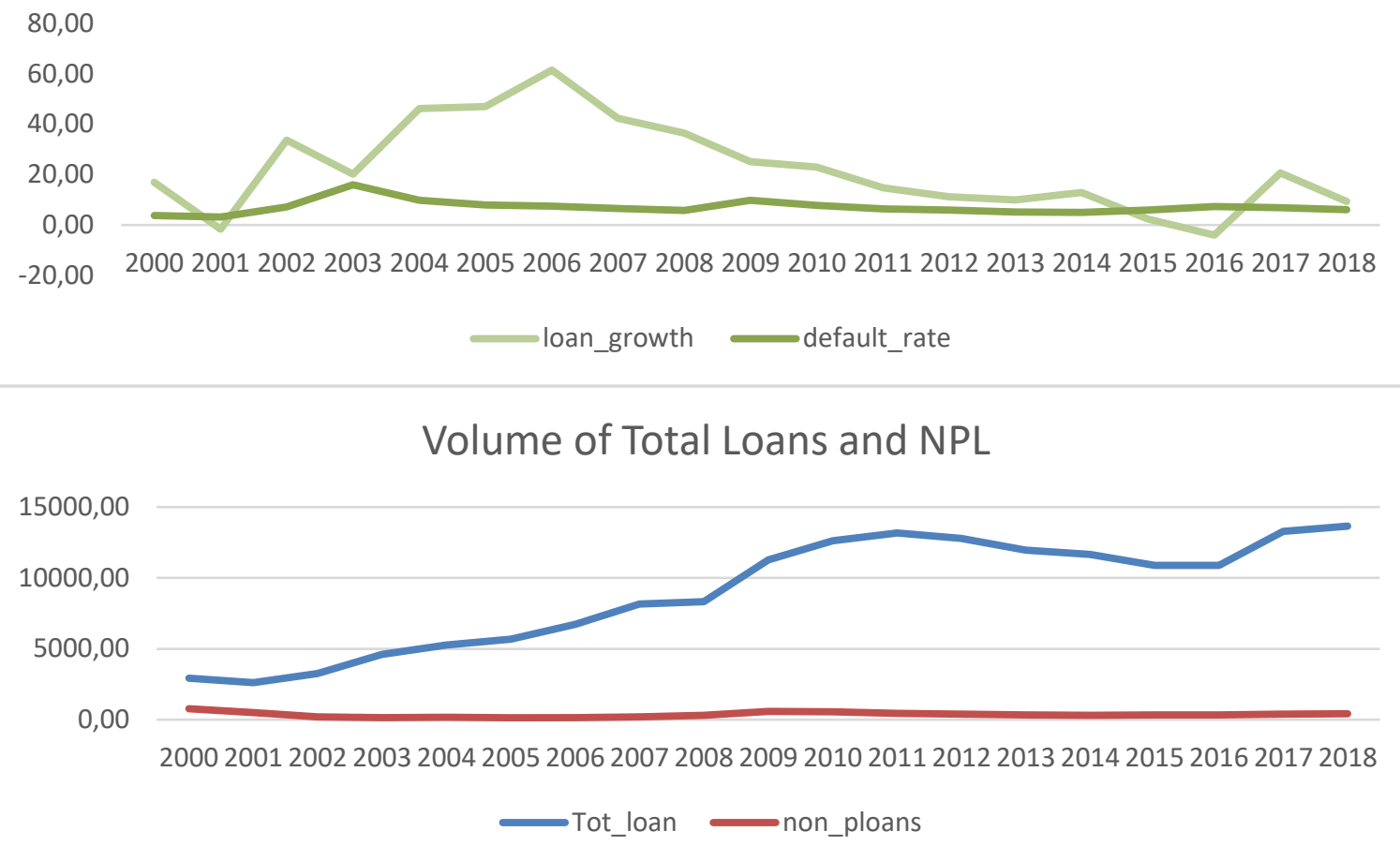

Figure 1. Lending growth rate in Africa 2000-2018

Source: Authors' calculation (2020)

Descriptive analysis of portfolio shift:

In line with the research objective, which examines African banks' responses to higher CAR in terms of portfolio shift, the study uses descriptive analysis, F-test, and KW test to achieve this objective. Table 3 provides the mean value of total loans and loan portfolios of banks in Africa under different Basel levels (Non-Basel compliance, Basel 2, or Basel 3). It aims to determine whether the banks engage in portfolio shifts among the loan categories with higher CAR. The result showed that total loans and all loan categories increased as the banks moved from Basel 2 to Basel 3. 
Table 3. Summary statistics: Portfolio shifts by Basel compliance

\begin{tabular}{|c|c|c|c|c|}
\hline Basel compliance & Non-Basel & Basel 2 & Basel 3 & Total \\
\hline Tot loan & 5475.02 & 10713.54 & 49758.15 & 9400.54 \\
\hline Cash and cash asset & 589.28 & 935.08 & 2573.58 & 789.37 \\
\hline Interbank asset & 752.39 & 930.25 & 4289.18 & 979.16 \\
\hline Commercial loan & 1613.65 & 1815.03 & 10271.91 & 2253.29 \\
\hline Consumer loan & 2047.05 & 3437.00 & 16180.44 & 3537.78 \\
\hline Credit card loan & 391.69 & 635.49 & 3168.43 & 1413.31 \\
\hline Residential loan & 4426.94 & 4703.55 & 19139.15 & 6372.95 \\
\hline Commercial mortg. & 754.06 & 1438.56 & 3710.69 & 1158.61 \\
\hline
\end{tabular}

Mean statistics: Authors' own calculation (2020)

In terms of bank size, South African banks are the largest in the sample. To effectively examine the portfolio shift of banks from other African countries, the study excluded South African banks as an outlier. The result is presented in Table 4 for descriptive statistics and Table 7 for ANOVA. After excluding South Africa, the summary results in Table 4 showed that, on average, higher Basel CAR increased total loans, cash, interbank lending, consumer loans, commercial loans, and credit card loans, but not residential and commercial mortgage loans. The results suggest other African banks engage in portfolio shifts by reducing lending to residential and commercial mortgage when the banks implemented Basel II. In addition, when banks change from Basel II to Basel III CAR, banks further reduced lending to residential and commercial mortgage. Total loans increased by an average of 130.03percent when other African banks moved from non-Basel compliance to Basel II CAR. Also, total loans increased by 121.14percent when banks implemented Basel III CAR. Even though total loans increased under Basel III, the loan growth declined by 8.98percent (130.03percent minus 121.14percent). 
Table 4: Summary statistics: Portfolio shifts by Basel compliance excluding South African banks

\begin{tabular}{lllll}
\hline Basel compliance & Non-Basel & Basel 2 & Basel 3 & Total \\
\hline Tot loan & 2116.16 & 4867.76 & 10764.78 & 3011.14 \\
Cash and cash asset & 353.00 & 710.92 & 834.47 & 450.68 \\
Interbank asset & 443.98 & 403.71 & 763.07 & 442.48 \\
Commercial loan & 863.99 & 1480.27 & 2093.74 & 1075.14 \\
Consumer loan & 650.71 & 1019.85 & 3390.08 & 850.83 \\
Credit card loan & 74.66 & 34.20 & 180.41 & 58.06 \\
Residential loan & 171.07 & 71.42 & 36.18 & 127.74 \\
Commercial mortg. & 149.10 & 183.76 & 153.36 & 158.01 \\
\hline
\end{tabular}

Mean statistics: Authors' calculation (2020)

Also, commercial loans declined by 29.89percent when other African banks adopted Basel III CAR, but consumer loans increased by 175.7percent. Credit card loans declined to -54percent under Basel II CAR, but credit card loans increased under Basel III CAR. In summary, change from Basel II to Basel III lead some banks that have implemented Basel III in other African countries (Egypt, Ghana, Kenya, Morocco, Nigeria, and Tanzania) to adjust their loan portfolio. These banks increase consumer loans and credit card loans with a moderate decline in commercial loans but more decline in residential and commercial mortgage.

South Africa has fully implemented Basel III CAR among the African countries, followed by Egypt. Table 5 separates the banks by African countries having information on more than three banks in compliance with Basel CAR in the sample dataset. For South African banks, total loans on average increased by 168.2percent with compliance to Basel II. However, moving from Basel II to Basel III, total loans have negative growth of 17.35percent. Other factors such as economic recessions could have accounted for this negative growth. But South African banks are known to be well-capitalized above the minimum Basel capital ratio of 8percent and 10percent, which could significantly affect bank lending. Despite the total loan decline with Basel III CAR, commercial loans for South African banks increased by 140.8percent. Also, consumer loans declined by 35.2percent with Basel III for South African banks

The result contrasts with the results in Table 4 for African banks where commercial loans declined by 29.89percent with Basel III, but total loans increased for banks in Table 4 with higher Basel CAR. Similar to African banks in Table 4, lending to residential and commercial mortgage decline with Basel III CAR for South African banks. 
D. Oyetade, A. A. Obalade, P.-F. Muzindutsi / ACRN Journal of Finance and Risk Perspectives 10 (2021) 296-319

Table 5. Summary Statistics: by categories of Basel compliance (Country)

\begin{tabular}{|c|c|c|c|c|c|c|c|c|c|}
\hline \multirow[t]{2}{*}{ Basel compliance } & \multicolumn{3}{|l|}{ Egypt } & \multicolumn{3}{|l|}{ South Africa } & \multicolumn{3}{|l|}{ Nigeria } \\
\hline & Non-Basel & Basel 2 & Basel 3 & Non-Basel & Basel 2 & Basel 3 & Non-Basel & Basel 2 & Basel 3 \\
\hline Tot loan & 2923.25 & 3264.55 & 11582.2 & 34178.01 & 91655.11 & 75753.74 & 2452.71 & 5091.72 & 7351.64 \\
\hline Cash and cash asset & 277.656 & 261.78 & 972.4 & 2646.71 & 4038.78 & 3732.98 & 912.29 & 1932.53 & 2854 \\
\hline Interbank asset & 527.10 & 578.64 & 2575.22 & 3722.25 & 8345.66 & 6933.77 & 1162.68 & 717.32 & 836.55 \\
\hline Commercial loan & 1310.8 & 1102.45 & 4289.62 & 7191.64 & 6724.8 & 16194.03 & 1249.23 & 2643.63 & 5450.76 \\
\hline Consumer loan & 734.65 & 336.82 & 1051.17 & 11097.36 & 35464.24 & 22975.32 & 164.87 & 276.8 & 164.53 \\
\hline Credit-card loan & 86.53 & 50.12 & 180.41 & 1501.3 & 2639.78 & 3467.23 & 3.45 & 8.54 & . \\
\hline Residential loan & 64.28 & 97.97 & 36.18 & 12437.97 & 31338.3 & 21049.45 & 57.6 & 26.33 & . \\
\hline \multirow[t]{2}{*}{ Commercial mortg. } & . & . & . & 3425.97 & 13359.12 & 6720.74 & 234.01 & 237.6 & 431.18 \\
\hline & Kenya & & & Ghana & & & Tanzania & & \\
\hline Basel compliance & Non-Basel & Basel 2 & Basel 3 & Non-Basel & Basel 2 & Basel 3 & Non-Basel & Basel 2 & Basel 3 \\
\hline Tot loan & 834.99 & 2208.18 & 2714.35 & 368.65 & 400.94 & 347.25 & 720.387 & 1851.51 & \\
\hline Cash and cash asset & 115.61 & 277.38 & 685.92 & 115.86 & 152.99 & 150.63 & 244.53 & 382.67 & \\
\hline Interbank asset & 60.58 & 126.83 & 164.45 & 142.54 & 172.76 & 34.02 & 142.77 & 139.03 & \\
\hline Commercial loan & 686.35 & 1373.75 & 2208.89 & 236.62 & 261.06 & 194.54 & 336.19 & 310.26 & \\
\hline Consumer loan & 129.53 & 226.55 & 505.2 & 11.87 & . & 119.00 & 298.55 & 201.21 & \\
\hline Credit-card loan & . & 5.57 & . & . & . & . & . & . & \\
\hline Residential loan & 8.234323 & 60.89 & . & . & . & . & . & . & \\
\hline Commercial mortg. & 96.57275 & 244.76 & . & 17.81 & . & 53.68 & 20.25 & 17.68 & \\
\hline
\end{tabular}

Mean statistics: Author's own calculation (2020) 


\section{ANOVA analysis of portfolio shift}

The study uses ANOVA (F-test and KW test) to examine the behaviour of banks if they engage in portfolio shift with higher Basel levels. Due to outliers in the dataset, the study uses a log transformation of the variables. Two hypotheses are formulated and tested using ANOVA (Table 6 and Table 7). The null hypothesis test $\mathrm{H}_{0}$ : The mean of portfolio shift is the same for banks for all Basel levels, and the alternate hypothesis $\mathrm{H}_{1}$ : The mean of portfolio shift is not the same for banks for all Basel levels.

F-test and KW test results reported in Table 6 shows that Tot_loan is significantly different when African banks move from Basel II to Basel III CAR at 1percent level of significance. Table 6 also shows that commercial loans, consumer loans, credit-card loans, residential and commercial mortgages are significantly different when African banks move from Basel II to Basel III CAR at 1percent level of significance. Therefore, the null hypothesis of equal mean in portfolio shift across the different Basel levels is rejected, suggesting that portfolio shifts among commercial loan, consumer loan, credit-card loans, residential and commercial mortgage loans differ between Basel II and III. In summary, the results imply that African banks engage positively in portfolio shift in compliance to Basel higher capital in the observable time period.

Table 6. ANOVA-F-test and KW-test for All African banks

\begin{tabular}{lcccc}
\hline Variables & F-test & P-value & Equal variance & KW-test \\
\hline Tot_loan & 59.88 & .0000 & .007 & .0001 \\
Commercial loan & 37.47 & .0000 & .000 & .0001 \\
Consumer loan & 33.20 & .0000 & 0.637 & .0001 \\
Creditcard loan & 23.60 & .0000 & .000 & .0001 \\
Residential loans & 22.35 & .0000 & .003 & .0001 \\
Commercial mortgage & 10.12 & .0001 & 0.662 & .0011 \\
\hline
\end{tabular}

Source: Author's own calculation (2020)

Table 7 excluded South African banks to examine whether the African banks (excluding South Africa) engage in portfolio shifts when they move to higher Basel levels. F-test and KW-test results reported in Table 7 show a significant difference in Tot_loan when African banks move from Basel II to Basel III CAR at 1percent significant level. The study rejects the null hypothesis of equal mean. In this scenario, using summary statistics in Table 4 where total loans increased under Basel III, the loan growth declined by 8.98percent, suggesting that as the Basel CAR increases, the total loans increases but the loan_growth reduces. 
Table 7: ANOVA-F-test and KW-test excluding South African banks

\begin{tabular}{lllll}
\hline Variables & F-test & Prob & Equal variance & KW-test \\
\hline Tot_loan & 24.37 & 0.0000 & 0.069 & 0.0001 \\
Commercial loan & 19.02 & 0.0000 & 0.001 & 0.0001 \\
Consumer loan & 1.52 & 0.2205 & 0.618 & 0.5168 \\
Creditcard loan & 7.41 & 0.0022 & 0.091 & 0.0018 \\
Residential loans & 2.06 & 0.1328 & 0.004 & 0.5985 \\
Commercial mortgage & 1.34 & 0.2652 & 0.349 & 0.1726 \\
\hline
\end{tabular}

Source: Author's own calculation (2020)

For commercial loans, the study rejects the null hypothesis. This suggests that African banks engage in portfolio shifts for commercial loans with higher Basel levels. Using the result in Table 4 in conjunction with the result in Table 7 for commercial loans, it is observed that higher Basel level decrease commercial loans. One possible reason for this decline is that African banks adopt selective Basel compliance; as such, there is no true equity capital to support loans. Higher Basel capital increases the capital level of banks, which should increase lending, but instead, the banks struggle to comply with minimum capital, as such affect lending for commercial loans.

For consumer loans, residential and commercial mortgages, the result of the F-test and KW-test are greater than 5percent significance level; therefore, the null hypothesis of equal mean cannot be rejected. The result suggests that African banks do not engage in portfolio shifts for consumer loans, residential and commercial mortgage when banks comply with higher Basel levels. One possible reason is that lending to these categories of loans by African banks is low. In contrast, the results also reported in Table 7 shows that there is a significant difference in credit card loans when African banks move from Basel II to Basel III CAR because they are statistically significant at the 5 percent level of significance. This leads to the rejection of the null hypothesis of equal mean. This suggests that banks engage in portfolio shifts with higher Basel levels for total loans, commercial loans and credit card loans.

\section{Discussion and findings}

The objective of the study was to examine African banks' responses to higher CAR in terms of portfolio shift. The findings show that compliance to higher Basel CAR has a different impact on bank lending behaviour in selected African countries. The findings show that African banks are adequately capitalised above the minimum CAR; however, the standard deviation test suggests that there are some banks operating below the minimum Basel II and Basel III CAR. This shows the inadequacy of bank regulatory authorities' enforcement of the Basel regulations within their jurisdictions. Also, many of the adequately capitalised African banks above the Basel II 8 percent minimum requirements adopt selective Basel requirements. Thus, the capital ratios are not estimated according to the Basel II accord requirements. As a result, the equity level vis-à-vis the disclosed capital ratios of most of these banks is low. 
Nevertheless, this study findings confirm that the implementation of Basel III CAR is beneficial to African banks for two reasons. Firstly, the minimum CAR of African banks increased by an average of 2 percent when the banks moved from Basel II to Basel III CAR. Secondly, total loans increased with an average growth rate of 268 percent when the banks moved from Basel II to Basel III CAR.

Furthermore, the study excluded South African banks due to their size and compliance to changes in Basel CAR to investigate the other African banks' responses to changes in Basel CAR across different loan categories. The results show that Basel II CAR led to an increase in total loans, cash and cash assets, commercial loans, consumer loans and commercial mortgages except for interbank assets, credit card loans and residential mortgages. For Basel III CAR, the study find that total loans and commercial loans increased at a decreasing loan growth declined, suggesting that the adoption of a higher Basel framework results in decline in loan growth rate. In addition, the African banks alter their lending behaviour, reducing cash and other cash assets as they adopt a Basel framework with high CAR. This result is contrary to Ashok and Abhiman (2002) findings that Indian banks hold more cash assets with higher level of CAR to boost their capital levels.

Nevertheless, the study establishes that African banks engage in portfolio shifts to meet higher CAR, reducing lending towards residential and commercial mortgage loans with higher risk weights. Only interbank assets, consumer loans and credit card loans have positive loan growth as the banks move from a lower CAR (Basel II) to a higher CAR (Basel III) framework. It is therefore established that the increase in total loans for African banks excluding South Africa arises from an increase in lending to loan categories such as consumer loans and credit card loans while cutting back lending in other loan categories such as residential mortgages, commercial mortgages and commercial loans to achieve higher CAR. The result is consistent with the findings of Haubrich and Wachtel (1993) and Ashok and Abhiman (2002), who found strong evidence between Basel regulatory capital ratio and bank portfolios' shift towards loans with low risk-weights in the United States and Indian banks, respectively. This implies that ccompliance to higher Basel CAR should increase lending to different loan categories. However, African banks still struggle due to low equity capital, selective Basel compliance and slow adoption of a higher Basel capital requirements.

In evaluating Basel compliance by individual countries, the study used countries having information of more than three banks that are in compliance with Basel CAR for data analysis. When African banks adopted Basel II CAR, total loans grew by over 100 percent for banks in South Africa, Nigeria, Kenya and Tanzania. Egypt had a slow loan growth of 11.68 percent and Ghana of 8.76 percent. Bank lending in Egypt was negatively affected by the implementation of Basel II CAR. Commercial loans, consumer loans, and credit card loans were negatively affected while interbank assets and residential mortgage increased marginally for Egyptian banks. Also, the Egyptian banks have no commercial mortgage loans. The negative effect Basel II requirement on loans growth indicates constrained growth on Egyptian banks' lending ability with their bank regulatory authority's enforcement of Basel II requirements. For Tanzania, the total loan increase, but the increase arises from increase in cash and cash assets only, while lending to all other loan categories declined with the implementation of Basel II CAR. There is no evidence that the Tanzanian bank regulatory authority enforces any Basel requirements. Therefore, these banks may have voluntarily adopted the Basel requirements for other reasons such as attracting foreign investments or deposits. 
Nigeria and Kenya's banks are the only African banks that witnessed increased commercial loans by a growth rate of over 100 percent following Basel II CAR implementation. South Africa had a negative growth rate in commercial loans of -6 percent. Summarising the effect of Basel II CAR for individual African countries, South African banks saw an increase in total loans, cash assets, interbank assets, consumer loans, credit card loans, residential loans and commercial mortgage loans. Kenyan banks saw an increase in total loans, cash assets, interbank assets, commercial loans, consumer loans, residential loans and commercial mortgage loans. Nigerian banks saw an increase in total loans, cash assets, commercial loans, consumer loans, credit card loans, and commercial mortgage loans. Banks in Egypt, Ghana and Tanzania struggled with loan issuance in all loan categories with Basel II CAR implementation.

For countries that are Basel III compliant, the study's findings show that the average total loans increased when Egypt, Nigeria, and Kenya banks moved from Basel II to Basel III CAR. Still, the reverse is the case for South Africa and Ghana. Furthermore, only Egypt has a positive total loan growth while Nigeria and Kenya total loan growth rate declined with Basel III CAR implementation. Basel III CAR represents a significant change in Basel capital regulations, introducing tangible common equity (TCE) and eliminating debt in calculating capital ratios (Yan et al., 2012). So, banks may engage in portfolio shifts to improve their capital positions, especially low capitalised banks. South Africa has well-capitalised banks above the minimum CAR, which could constrain bank lending, while Ghana has banks with low capital ratios inhibiting these banks from increasing lending. This findings is similar to the finding of Ashok and Abhiman (2002), who showed that total loans for under-capitalised and over-capitalised banks declined with higher capital in India. Commercial loans for all the observed individual African countries on the average increased (except for Ghana and Tanzania) with the implementation of Basel III CAR. These findings suggest that compliance to Basel III CAR will have a positive impact on economic growth in Africa as businesses get more financial support from the African banks. However, in terms of loan growth, commercial loans growth declined by 8.98percent with Basel III CAR. The result is consistent with Juelsrud and Wold (2020), who find that implementation of Basel III CAR declined commercial loans for Norwegian banks.

Egypt and South Africa are the two countries with full implementation of Basel III capital requirements. Comparing the effect of the Basel changes on bank lending, Egyptian banks saw an increase in all loan categories except for commercial mortgage with the implementation of Basel III CAR, while South African banks saw an increase in commercial loans and credit card loans, but other loan categories declined including total loan output. The results show that Basel regulations are beneficial for poorly regulated and inefficient banks, as shown in the case of Egypt and other African countries like Kenya and Nigeria. South African banks benefitted when they implemented Basel II CAR, which significantly increased total loans and other loan categories. However, strict regulations in the South African banks hinder banks from increasing lending for profitable returns (Abdel-Baki, 2012).

Comparing the effect of changes in Basel CAR on bank lending among other countries that have not fully implemented Basel III CAR, such as Kenya, Nigeria, Ghana and Tanzania, the result show that each of these countries engages in portfolio shift in different loan categories. For example, Kenyan banks total loans, commercial loans, and consumer loans increased moving from Basel II to Basel III. Nigerian banks commercial loans increased but witnessed decline in consumer loans, credit card loans and residential loans. The volume of commercial loans increased with Basel III CAR, but at a declining growth rate, especially for Nigeria and Kenya banks. In general, 
Nigeria, Kenya, Ghana, and Tanzania struggle with credit card loans, residential mortgage loans, and commercial mortgages. Nevertheless, commercial mortgage for Nigerian banks increased at a decreasing rate with the implementation of Basel III CAR. Egypt and South Africa declined lending to commercial mortgage with Basel III CAR. The result is not consistent with Junge and Kugler (2013) who find that Swiss banks did not engage in portfolio shift in compliance to Basel III CAR.

The ANOVA significance test suggests that African banks engage in portfolio shift when a higher Basel CAR is adopted. In this context, the results show that African banks increase their portfolio shares in all loan categories with higher Basel CAR. However, excluding South African banks due to their size, the ANOVA significance test suggest that the remaining African banks engage in portfolio shift by increasing their portfolio shares for total loans, commercial loans and credit card loans. Overall, findings show that total loan output for African banks increased with higher Basel CAR. Thus, African banks engage in portfolio shifts moving from one loan category to another instead of moving from loans with high risk-weights such as commercial loans to government securities with zero riskweights as witnessed in Haubrich and Wachtel (1993) for US banks and Ashok and Abhiman (2002) for Indian banks.

The result for South African banks is inconsistent with Neethling (2014)'s findings that South African banks do not engage in portfolio shift because they are capitalised above minimum CAR. Neethling (2014) results stopped in 2013, the year Basel III capital was implemented in South Africa, so these findings are true for South African banks' behaviour under Basel II. The results of the portfolio shift for African banks do not conform to the Modern Portfolio Theory, which implies that a firm attempts to maximise its expected return on a portfolio of assets for a given level of portfolio risk. In this context, the banks are expected to increase lending to risky loans for higher returns to shareholders with higher Basel CAR. Instead, the African banks' behaviour to portfolio allocation is based on avoiding falling below minimum regulatory capital to avoid regulatory penalties. For these reasons, African banks decrease issuing loans with high-risk weights such as real estate loans to improve their capital ratios. According to Waithaka (2013), such behaviour occurs for banks with low capitalized environment as Banks with low capital grow slower than the well-capitalized banks. In addition, there are African banks with adequate capital that are not effectively utilized accordingly, which is contrary to the premise that well-capitalized banks have more capacity to expand and diversify loan assets. These results expose the inefficiency of regulatory authorities in many African countries that adopt selective Basel CAR. Consumer, corporate, and credit card loans are usually short to mediumterm loans, while residential and commercial mortgages are long-term loans. Due to low equity levels, African banks may not be willing to tie down capital for long-term loans, as such limits their lending to commercial loans, residential and commercial mortgage.

In individual African countries, institutional frameworks may affect the banks' movement from residential and commercial mortgage toward loans with less risk-weight. Securitisation provides an additional source of liquidity for banks allowing banks to convert illiquid loans to liquid funds to finance more illiquid long-term loans (Loutskina, 2011). However, African banks have not embraced securitization (Oyetade, Obalade, \& Muzindutsi, 2020). Also, the lack of special purpose vehicles for securitisation activities may limit African banks to lend towards residential and commercial mortgages. In addition, most African banks are yet to fully comply with Basel II or III CAR except for South Africa and Egypt that fully enforced the implementation of Basel II and Basel III and benefited from increased 
lending. These factors explain why African banks engage in loans with low-risk weight and reduce loans with highrisk weights.

Our study reveals that capital ratios of African banks increased with higher Basel CAR, although, African banks moved away from loans with higher risk-weights mortgages and corporate loans with Basel III CAR. This suggest that higher Basel CAR impact on African banks portfolio shift behaviour. Our study findings is in line with Juelsrud and Wold (2020) for Norwegian banks; Haubrich and Wachtel (1993) for US commercial banks which concluded that portfolio shift are strongly related to changes in Basel capital requirements as a result of the risk-weighting system. Also, our study findings for African banks are contrary to the static trade-off theory which suggests that compliance to Basel CAR forces banks to hold capital above the optimal level, which influence risk taking behaviour of banks to maximise returns to shareholders.

\section{Concluding remarks}

This study examined whether changes in Basel CAR leads to the shift in portfolio of banks in Africa. The result presented strongly suggests that African banks engage in portfolio shift with higher Basel levels. Higher capital increased the capital ratios of the African banks. Higher capital increased the total loans and all other loans categories except for real estate loans for African banks. Basel II and Basel III capital requirements alter the lending behaviour of African banks differently. These Basel levels with different capital requirements influence how African banks allocate funds to different loan categories.

The lending behaviour of the African banks following the implementation of higher Basel CAR offers new insight into the effects of bank regulations in African commercial banks. The study establishes that African banks engage in portfolio shifts to meet higher CAR. Changes in Basel CAR influence African banks loans differently across jurisdictions. Implementation of Basel II and Basel III CAR increased different loan categories except for real estate loans (residential and commercial) for African banks except South African banks. Commercial loans increased on average with the implementation of Basel II and Basel III CAR; however, commercial loan growth declined with Basel III CAR. In addition, African banks allocate more funds in their loan portfolio to consumer loans and interbank assets with Basel III CAR. Higher Basel CAR impact on African banks (except Ghana and Tanzania) portfolio shift behaviour positively except real estates. In other words, the banks continued lending in their loan categories when they implemented Basel II and Basel III CAR compared to banks in developed countries or other emerging countries that engage in portfolio shift towards cash assets that led to the credit crunch in the United States in 1991, also, portfolio shift towards residential mortgages that increase portfolio risks that led to the Japan bank failures in 1998 and 2008 global financial crises.

In summary, higher Basel CAR increased the capital ratio of the banks in Africa, which is relevant to improving African banking stability and resilience to support economic growth. However, many African countries adopt selective Basel requirements, and the banks' equity capital is low for capital adequacy to facilitate increase in bank lending. Basel II CAR increased bank lending for African banks, especially Kenya, South Africa and Nigeria except Egypt. Much more, moving from Basel II to Basel III CAR increased the total loans in volume even though loan growth declined for African banks. Nevertheless, higher Basel CAR reduced non-performing loans. Concentration 
of loans in selected loan categories without loan diversification and adequate capital can weaken the bank resilience during extreme periods. Higher Basel CAR is beneficial to African banks to increase loan diversification, especially now that the world is currently experiencing the Covid-19 pandemic, which resulted in several months of lockdowns with only essential businesses in operation. For this reason, banks engaging in portfolio shifts (for instance, consumer loans in the case of African banks) as a response to higher Basel CAR prior to the pandemic without diversification of loan portfolio may become overly exposed as borrowers have credit problems to repay their loans. To achieve higher Basel capital in Africa, bank regulators in African countries should implement the higher Basel standards over a medium-term period to allow banks to prepare to prevent a reduction in credit allocation to different sectors in the economy in the short term. Also, the bank regulators should pay attention to African banks portfolio shifting incentives and behaviour of African banks with the higher Basel CAR implementation to avoid negative effect on economic growth. Egypt, South Africa and Nigeria bank sizes and loan volume increased with Basel II/III implementation. However, many African countries are slow in adopting Basel II or Basel III CAR instead they adopt selective Basel requirements into their national banking regulations. These national regulations are outdated, which weakens banks resilience as the banks grow, constrain innovative banking products and impose too much control, which stifle African banks' ability to increase lending. It is recommended that bank regulatory authorities in Africa upgrade their Banking Acts according to new and higher Basel requirements for standardized calculation of riskweighted assets by the banks to enable the banks hold adequate capital against assessed risk exposure rather than arbitrary capital reserves imposed on African banks above their risk level. In addition, enforcement of the Basel requirements by the bank regulatory authorities across jurisdictions in Africa to reduce bank failures, fragility, and improve bank lending abilities is also necessary. Overall, the implementation of higher Basel CAR increased the capital positions of banks and total loans volume in Africa; higher CAR, should be embraced with caution. 


\section{References}

Abdel-Baki, M. (2012). Forecasting the Costs and Benefits of Implementing Basel III for North African Emerging Economies: An Application to Egypt and Tunisia. African Development Bank, Economic Brief, 1-40. Retrieved from www.afdb.org.

Admati, A. R., DeMarzo, P. M., Hellwig, M. F., \& Pfleiderer, P. C. (2013). Fallacies, irrelevant facts, and myths in the discussion of capital regulation: Why bank equity is not socially expensive. Max Planck Institute for Research on Collective Goods, 23, $1-77$.

Allen, F. \& Giovannetti, G. (2011). The effects of the financial crisis on Sub-Saharan Africa. Review of Development Finance, 1(1), 1-27. doi:https://doi.org/10.1016/j.rdf.2010.10.002.

Ambrocio, G., \& Jokivuolle, E. (2018). Should bank capital requirements be less risk-sensitive because of credit constraints? Research Discussion Papers, No. 10/2017. Bank of Finland 1-58. Retrieved from http://hdl.handle.net/10419/212381.

Andrianova, S., Baltagi, B., Demetriades, P., \& Fielding, D. (2015). Why Do African Banks Lend So Little? Oxford Bulletin of Economics and Statistics, 77(3), 339-359. doi:10.1111/obes.12067.

Ashok, K. N., \& Abhiman, D. (2002). Credit Growth and Response to Capital Requirements: Evidence from Indian Public Sector Banks. Economic and Political Weekly, 37(32), 3361-3368. Retrieved from http://www.jstor.org/stable/4412468.

Asiama, G. K., \& Amoah, A. (2019). Non-performing loans and monetary policy dynamics in Ghana. African Journal of Economic and Management Studies, 10(2), 169-184. doi:10.1108/AJEMS-04-2018-0103.

Asongu, S., \& Odhiambo, N. M. (2018). Testing the quiet life hypothesis in the African banking industry. Working Paper. African Governance and Development Institute (AGDI), Yaoundé 18(015), 1-21. Retrieved from http://hdl.handle.net/10419/191338.

Balin, B. J. (2008). Basel I, Basel II, and emerging markets: A Nontechnical Analysis. The Johns Hopkins University School of Advanced International Studies (SAIS), Washington DC 20036, USA, 18.

BCBS. (2009). Strengthening the resilience of the banking sector. Basel Committee on Banking Supervision. Retrieved from https://www.bis.org/publ/bcbs164.pdf.

BCBS. (2010). An assessment of the long-term economic impact of stronger capital and liquidity requireme. Basel Committee for Banking Supervision, 1-69. Retrieved from http://www.bis.org.

BCBS. (2016). Revisions to the securitisation framework. Amended to include the alternative capital treatment for "simple, transparent and comparable" securitisations. Basel Committee on Banking Supervision, 1-60. Retrieved from www.bis.org.

BCBS. (2017). Basel III: Finalising post-crisis reforms. Basel Committe on Banking Supervision, 1-162. Retrieved from http://www.bis.org.

Benetton, M., Eckley, P., Garbarino, N., Kirwin, L., \& Latsi, G. (2020). Capital requirements and mortgage pricing: Evidence from Basel II. Journal of Financial Intermediation, 100883. doi:https://doi.org/10.1016/j.jfi.2020.100883.

Bennett, P. (1984). Applying portfolio theory to global bank lending. Journal of Banking \& Finance, 8(2), 153-169. doi:https://doi.org/10.1016/0378-4266(84)90002-5.

Bennett, P. (1999). Portfolio Theory and Bank Lending: Avoiding concentrations of credit risk through strategic diversification. The Journal of Lending \& Credit Risk Management, 64-67. Retrieved from https://cms.rmau.org/.

Berger, A. N., Herring, R. J., \& Szegö, G. P. (1995). The role of capital in financial institutions. Journal of Banking \& Finance, 19(3), 393-430. doi:https://doi.org/10.1016/0378-4266(95)00002-X.

Berger, R. (2017). Implications of ongoing "Basel IV" debates. Significant new constrainsts to come for banks, with expected ramifications for European economy financing. Retrieved from Online: www.rolandberger.com.

Bernanke, B. S., Lown, C. S., \& Friedman, B. M. (1991). The Credit Crunch. Brookings Papers on Economic Activity, 1991(2), 205-247. doi:10.2307/2534592.

Berrospide, J. M., \& Edge, R. M. (2010). The effects of bank capital on lending: What do we know, and what does it mean? International Journal of Central Banking, 6(4), 1-50.

Bikker, J. A., \& Vervliet, T. M. (2018). Bank profitability and risk-taking under low interest rates. International Journal of Finance \& Economics, 23(1), 3-18. doi:10.1002/ijfe.1595.

Bruno, B., Nocera, G., \& Resti, A. (2017). Are risk-based capital requirements detrimental to corporate lending? : Evidence from Europe. Centre for Economic Policy Research, 1-35.

Carbó-Valverde, S., Marqués-Ibáñez, D., \& Rodriguez-Fernandez, F. (2011). Securitization, Bank Lending and Credit Quality: The Case of Spain. European Central Bank, 1-44. Retrieved from http://www.ecb.europa.eu.

Chironga, M., Cunha, L., Grandis, H. D., \& Kuyoro, M. (2018). African retail banking's next growth frontier. Retrieved from Online: https://www.mckinsey.com/industries/financial-services/our-insights/african-retail-bankings-next-growth-frontier.

Cummings, J. R., \& Wright, S. (2016). Effect of Higher Capital Requirements on the Funding Costs of Australian Banks. Australian Economic Review, 49(1), 44-53. doi:10.1111/1467-8462.12138.

Datta, C. K., \& Mahmud, A. A. (2018). Impact of Capital Adequacy on Profitability Under Basel II Accord: Evidence from Commercial Banks of Bangladesh. European Journal of Business Management, 10(8), 48-58. Retrieved from www.iiste.org.

Demetriades, P., \& Fielding, D. (2012). Information, institutions, and banking sector development in West Africa. Economic Inquiry, 50(3), 739-753.

Derina, R. (2011). The impact of changes of capital regulations on bank capital and portfolio risk decision: a case study of Indonesian banks. The University of Adelaide, Retrieved from http://hdl.handle.net/2440/70208. 
Dionne, G., \& Harchaoui, T. M. (2008). Banks' capital, securitization and credit risk: An empirical evidence for Canada. Journal of Insurance and Risk Management, 75(4), 459-485.

European Investment Bank. (2016). Banking in sub-Saharan Africa: Recent trends and digital financial inclusion. Regional Studies and Roundtables, European Investment Bank, 1-179.

Furfine, C. (2001). Bank Portfolio Allocation: The Impact of Capital Requirements, Regulatory Monitoring, and Economic Conditions. Journal of Financial Services Research, 20(1), 33-56. doi:10.1023/A:1011147609099.

Gavalas, D. (2015). How do banks perform under Basel III? Tracing lending rates and loan quantity. Journal of Economics and Business, 81, 21-37. doi:https://doi.org/10.1016/j.jeconbus.2015.05.003.

Hamilton, L. (2003). Statistics with Stata. Updated for version 7: Thomson Learning, Inc.

Hancock, D., \& Wilcox, J. A. (1994). Bank Capital and the Credit Crunch: The Roles of Risk-Weighted and Unweighted Capital Regulations. Real Estate Economics, 22(1), 59-94. doi:https://doi.org/10.1111/1540-6229.00626.

Haubrich, J. G., \& Wachtel, P. (1993). Capital requirements and shifts in commercial bank portfolios. Federal Reserve Bank of Cleveland Economic Review 29 (Quarter 3).

Iwatsubo, K. (2007). Bank capital shocks and portfolio risk: Evidence from Japan. Japan and the World Economy, 19(2), 166186. doi:https://doi.org/10.1016/j.japwor.2005.09.001.

Jablecki, J. (2009). The impact of Basel I capital requirements on bank behavior and the efficacy of monetary policy. International Journal of Economic Sciences and Applied Research, 2(1), 16-35.

Juelsrud, R. E., \& Wold, E. G. (2020). Risk-weighted capital requirements and portfolio rebalancing. Journal of Financial Intermediation, 41, 100806. doi:https://doi.org/10.1016/j.jfi.2018.10.002.

Junge, G., \& Kugler, P. (2013). Quantifying the impact of higher capital requirements on the Swiss economy. Swiss Journal of Economics and Statistics, 149(3), 313-356. doi:10.1007/BF03399394.

Kahari, L. R. (2016). Impact of Basel Accords in mitigating banking fragility in Africa. Wits Business School, Online.

Ljung, A., \& Schennings, A. (2018). The impact of capital requirements on Swedish bank lending: A study on the effects of higher capital regulations. Lund University, Retrieved from http://lup.lub.lu.se/.

Loutskina, E. (2011). The role of securitization in bank liquidity and funding management. Journal of Financial Economics, 100(3), 663-684. doi:https://doi.org/10.1016/j.jfineco.2011.02.005.

Mapororo, B. (2018). The determinants of capital structure and internal factors that influence the performance of commercial banks in Botswana. University of Cape Town, Retrieved from http://hdl.handle.net/11427/29732 Available from University of Cape Town OpenUCT database.

Mecagni, M., Marchettini, D., \& Maino, M. R. (2015). Evolving banking trends in Sub-Saharan Africa: Key features and challenges: International Monetary Fund.

Moise, I. (2018). Wells Fargo's loan book shrinks, profit misses estimates. Reuters, pp. 1-5. Retrieved from https://www.reuters.com/article/us-wells-fargo-results/wells-fargos-loan-book-shrinks-profit-misses-estimatesidUSKBN1K31OA.

Myers, S. C. (1984). The Capital Structure Puzzle. The Journal of Finance, 39(3), 574-592. doi:10.1111/j.15406261.1984.tb03646.x.

Nachane, D., Narain, A., Ghosh, S., \& Sahoo, S. (2000). Capital adequacy requirements and the behaviour of commercial banks in India: An analytical and empirical study. Development Research Group Study. Department of Economic Analysis and Policy Reserve Bank of India(22).

Neethling, S. B. (2014). Empirical evidence of aggregate credit supply by South African banks since the introduction of international risk based capital regulation. University of Cape Town, Retrieved from http://hdl.handle.net/11427/8569 Available from University of Cape Town OpenUCT database.

Nkopane, T. (2017). The relevance of the Basel III Accord within the South African banking system. Wits University, South Africa Online. Retrieved from http://wiredspace.wits.ac.za.

Noss, J., \& Toffano, P. (2016). Estimating the impact of changes in aggregate bank capital requirements on lending and growth during an upswing. Journal of Banking \& Finance, 62, 15-27. doi:https://doi.org/10.1016/j.jbankfin.2015.09.020.

Okoye, L. U., Adetiloye, K. A., Erin, O., \& Evbuomwan, G. O. (2017). Impact of banking consolidation on the performance of the banking sector in Nigeria Journal of Internet Banking and Commerce, 22(1), 1-15. Retrieved from http://www.icommercecentral.com.

Osborne, M., Fuertes, A., \& Milne, A. (2012). Capital and profitability in banking: Evidence from US banks. 3rd Emerging Scholars in Banking and Finance Conference, Cass Business School, 1-54. Retrieved from https://www.cass.city.ac.uk/ data/assets/pdf_file/0013/152122/Osborne_Matthew_Capital-and-earnings-in-banking-

Emerging-Scholars.pdf.

Oyetade, D., Obalade, A., \& Muzindutsi, P.-F. (2020). Impact of the Basel IV framework on securitization and performance of commercial banks in South Africa. Banks and Bank Systems, 15(3), 95-105. doi:10.21511/bbs.15(3).2020.09.

Perrone, Ferreira, \& Securato. (2015). Basel III: Impact on Banks in Brazil. Revista Contabilidade \& Financas, $26(69), 345-361$. doi:http://dx.doi.org/10.1590/1808-057x201500720.

Psillaki, M., \& Georgoulea, E. (2016). The Impact of Basel III Indexes of Leverage and Liquidity CRDIV/CRR on Bank Performance: Evidence from Greek Banks. SPOUDAI Journal of Economics and Business, 66(1-2), 79-107. Retrieved from https://spoudai.unipi.gr/index.php/spoudai/article/viewFile/2541/2615. 
Roulet, C. (2018). Basel III: Effects of capital and liquidity regulations on European bank lending. Journal of Economics and Business, 95, 26-46. doi:https://doi.org/10.1016/j.jeconbus.2017.10.001.

Ruthenberg, D., \& Landskroner, Y. (2008). Loan pricing under Basel II in an imperfectly competitive banking market. Journal of Banking \& Finance, 32(12), 2725-2733. doi:https://doi.org/10.1016/j.jbankfin.2008.07.009.

Sanders, T. B. (2015). The Unintended Consequences of Basel III: Reducing Performance Ratios and Limiting Bank Acess to Equity Funding Markets. Quarterly Journal of Finance and Accounting, 53(1/2), 97-144. Retrieved from www.jstor.org/stable/24634491.

Sanusi, L. (2010). Global financial meltdown and the reforms in the Nigerian banking sector Paper presented at the BIS Central Bankers' speeches, Convocation Square, Abubakar Tafawa Balewa University, Bauchi, Nigeria.

Soile-Balogun. (2017). Bank failures and the impact of regulatory reforms in Africa. (Master). University of the Witwatersrand, Online.

Tabak, B. M., Noronha, A. C., \& Cajueiro, D. (2011). Bank capital buffers, lending growth and economic cycle: empirical evidence for Brazil. 2nd BIS CCA Conference on "Monetary policy, financial stability and the business cycle, 1-26. doi:http://citeseerx.ist.psu.edu/viewdoc/download?doi=10.1.1.465.8674\&rep=rep1\&type=pdf.

Waithaka, N. N. (2013). The effect of Basel II requirement on Kenyan commercial banks' lending. (MSc, Finance). University of Nairobi, Online. Retrieved from http://erepository.uonbi.ac.ke/handle/11295/63349.

Walter. (2019). US Bank Capital Regulation: History and Changes Since the Financial Crisis. Economic Quarterly(1Q), 1-40.

Welch, B. L. (1947). The Generalization of 'Student's' Problem when Several Different Population Variances are Involved. Biometrika, 34(1/2), 28-35. doi:10.2307/2332510.

World Bank. (2020). Bank nonperforming loans to total gross loans (\%). Retrieved from: https://data.worldbank.org/indicator/.

Yan, M., Hall, M. J. B., \& Turner, P. (2012). A cost-benefit analysis of Basel III: Some evidence from the UK. International Review of Financial Analysis, 25, 73-82. doi:10.1016/j.irfa.2012.06.009.

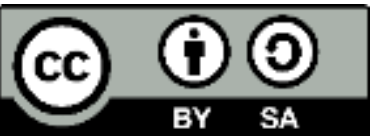

(C) 2021 by the authors. Licensee ACRN Publishing, Austria, Editor in Chief Prof. Dr. Othmar M. Lehner. This article is an open access article distributed under the terms and conditions of the Creative Commons Attribution (CC BY SA) license (https://creativecommons.org/licenses/by-sa/4.0/) 